\title{
Law sends laboratories into pathogen panic
}

Erika Check, Washington

When unknown parties mailed anthrax spores to several US addresses in the autumn of 2001, plant researchers at a herbarium at Harvard University began to get nervous.

For years, the researchers had stored a set of innocuous-looking brown envelopes that contained samples of anthrax. Within weeks of the attacks, President George W. Bush had signed a law called the USA Patriot Act, under which possession of anthrax without a "bona fide research justification" became a criminal offence. The Harvard researchers soon found themselves facing a tricky dilemma - how to balance their hoarding instincts against the new demands of homeland security.

As thousands of US biologists face up to the same problem, some scientific leaders are concerned that researchers are dumping valuable samples to avoid trouble with the law.

For example, Ron Atlas, president of the American Society for Microbiology, is alarmed by the prosecution last July of a University of Connecticut graduate student who kept anthrax in his freezer. Atlas says these old microbes could hold useful information. "We are really in a delicate balance as to whether individuals will hold on to their cultures or whether they'll feel endangered by the USA Patriot Act," he says. He also warns that those who clear out their freezers may have problems restocking them because of new restrictions on the movement of pathogens between labs.

Some institutions - such as Iowa State University at Ames, which destroyed its entire archive of anthrax samples in October 2001 have ordered mass clear-outs of materials. But individual researchers have also taken it upon themselves to dump potentially dangerous microbes. John Collier, a Harvard microbiologist who has long worked on the anthrax toxin, got rid of his samples of the bacteria late in 2001. "I wanted to be able to tell the world we didn't have Bacillus anthracis," Collier says.

The issue has now attracted the White House's attention - in part because archived samples could prove useful in criminal investigations. Kathryn Harrington, a spokeswoman for the administration's Office of Science and Technology Policy, says that the office is "aware of the destruction of select agents and is concerned". She adds that the office is trying to "encourage researchers to transfer materials to a secure facility, rather than destroy them".

This is exactly what the Harvard plant scientists did, after consulting their colleague molecular biologist Matthew Meselson. He contacted Paul Keim, a microbiologist at Northern Arizona University in Flagstaff who has spent his career studying anthrax. Keim persuaded the Harvard scientists to send him their envelopes, which are thought to contain anthrax taken from the blood of a cow in 1883. "We were interested in these for basic

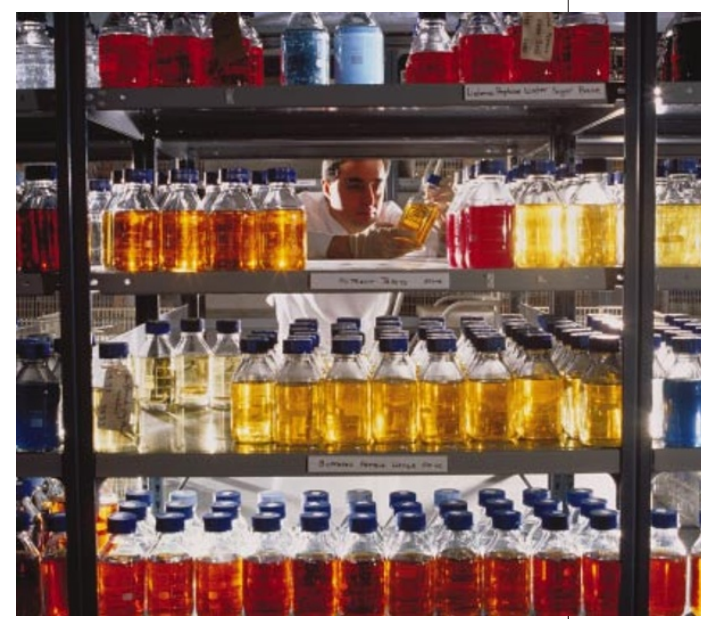

Bottling it: biologists are jettisoning their collections to avoid falling foul of legislation.

pathogen-evolution studies," Keim says. "But now they're crucial for fighting bioterrorism."

Keim also argues that the federal government should use some of its new bioterrorism funds to solve the problem once and for all by creating a central repository for pathogens. "There's a big problem with saving these collections and a big problem with getting access to them," Keim says. "What's the point of putting $\$ 1.7$ billion into the research if nobody can get hold of the strains?"

\section{Biotech critic tries to sew up research on chimaeras}

\section{Erika Check, Washington}

Scientists who are seeking to meld human embryonic stem cells with mouse embryos have been warned that they could be sued if they pursue the idea.

The 'chimaeric' embryos would be used to test the stem cells' ability to divide into cells with different functions (see Nature 420, 255; 2002). But Jeremy Rifkin, an

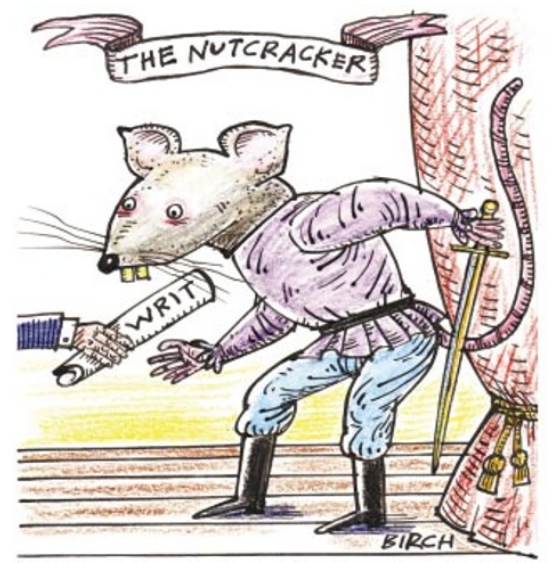

economist and well-known critic of the biotechnology industry, has told researchers to abandon their plans, claiming that he is about to win a wide-ranging patent on human-animal chimaeras.

"They're saying they cannot take advantage of therapeutic cloning with stem cells unless they place them in an animal model," Rifkin says. "And we're saying we control that."

Rifkin and Stuart Newman, a cell biologist at New York Medical College, applied for the patent in 1997. So far, examiners at the US Patent and Trademark Office have said three times that the application should be turned down - but it remains under review. Rifkin claims that he will prevail in a court appeal even if the patent office denies his claims.

Rifkin's lawyers have sent letters asserting the claims to prominent researchers in the field, including Ali Brivanlou, a developmental biologist at Rockefeller University in New York, Austin Smith of the University of Edinburgh, UK, and James Thomson of the University of Wisconsin at Madison.
But Brivanlou, one of the researchers working on a discussion paper considering the production of chimaeric embryos, says he is undeterred by the letter. "This certainly isn't going to stop me from doing anything," he says. "I'm not taking it seriously."

Brivanlou says that he is highly sceptical of Rifkin's warnings. He points out that Rifkin has not been awarded a patent and that Rifkin and Newman have not done the experiments described in their patent application as proof that it is possible to make a chimaeric embryo.

Rifkin and his lawyer contend that they don't have to make a chimaera to win a patent on it. "There is no rule, regulation, case law or statute of which I'm aware that requires the inventor to practise his or her invention,” says Patrick Coyne, Rifkin's lawyer at the Washington firm Collier Shannon Scott.

A lawyer not associated with the case says that although this is technically correct, courts have recently asked for proof that biotechnology inventions actually work before granting patents on them. 